\title{
EDITORIAL
}

\section{Giving Back to Your Country, the People, and Your Family}

\author{
Chitranjan S. Ranawat, MD
}

Received: 17 May 2010/Accepted: 18 May 2010/Published online: 30 July 2010

(C) Hospital for Special Surgery 2010

We are pleased to reproduce Dr. Chitranjan Ranawat's address to the American Academy of Orthopedic Surgeons Class of 2009. This was delivered at the ceremony which honors their induction into the Academy. In this speech, Dr. Ranawat reflects on many of the responsibilities that accompany a career in orthopaedics, and he emphasizes that a truly dedicated surgeon is committed throughout his or her career to service to their community. Many of us might argue that the demanding education and training and the arduous work schedule and daily stress that are inherent to this career are obligations enough. However, Dr. Ranawat, whose career has exemplified the qualities of the master surgeon, argues that more is required from all of us.

I believe that there is vital importance in the preservation of the thoughts and examples of the personal attributes of leaders. Leadership is not an innate characteristic. It must be learned, and the future of our profession will depend in many respects on how well our future leaders receive their training. Dr. Ranawat has performed a service towards this end by sharing his personal reflections. Please enjoy reading it.

Charles N. Cornell, MD

Editor-in-Chief

Giving back to your country, the people, and your family

It is with a great personal sense of pride and fulfillment that I welcome the graduating class of 2009. Today, my special thanks to the leadership of the Academy, especially Dr. Tony Rankin, for the honor and privilege of being here with you today.

C. S. Ranawat, MD (

Hospital for Special Surgery,

535 East 70th Street, New York, NY 10021, USA

e-mail: rocinny@rocinny.com

C. S. Ranawat, MD

Weill Cornell Medical College,

New York, NY 10065, USA
Forty-five (45) years ago, who would have thought that I would have the privilege to stand on this podium, to address you all. Certainly not me or my parents. I came to this country from India, alone, at the age of 28 , without any friends or family, and with limited financial resources.

The United States of America is the only country I know of where first- and second-generation immigrants can rise to their full potential. Just think how fortunate we all are to practice medicine in this country. I urge the members of the AAOS to remain together to preserve and grow our specialty, take it to a higher level, and play a major role in Washington. You, the graduating class, are the future of Orthopaedics and you all should participate with heart and soul.

By choosing our 44th President, Barack Obama, the son of an African immigrant, this country and its people have provided further evidence how great America is. The greatness of this country lies in providing safety to people, legacy of freedom - of speech, of the press, of life, liberty, and the pursuit of happiness, as envisioned two centuries ago by the founding fathers to create this democracy, guaranteed by the Constitution and protected by our brave men and women in uniform (military and police).

Now I come to my main theme, giving back in life and profession is important and needs to be emphasized. What you have acquired in your life, you should share with those who are not that privileged or possess less. I am going to touch on three aspects of giving back. The first relates to financial success and philanthropy. Many of us have or will achieve financial success through the profession or otherwise. If this be the case, I say it is time to share it with those who have less or need more. Philanthropy in general, in American society, is an important aspect of the lives of people who have succeeded.

The second aspect of giving back relates to our professional obligation for sharing knowledge and time and giving the best care to your patients. Giving back in our profession is to give back one's precious time and knowledge to help in education, research, art, and science of surgery. We as physicians have the moral obligation to treat patients with compassion, honesty, dignity, and respect. 
Needless to say, it should be based on evidence and to satisfy a patient's need.

The third kind of giving relates to assuming roles of distinguished leadership. Such distinguished leadership which occurs very infrequently is when people such as Mahatma Gandhi, Martin Luther King, Dalai Lama, Sister Theresa, and others give back all what they possess in their life to achieve peace, equality, and justice. Allow me to talk about the three principles I have lived with.

The following life-affirming principles have imparted meaning in my own life: Nothing endures but change (Heraclitus 480 BC).

Change is very powerful; it for sure sets the tone to be different. The way I understand it is that it could be either better or worse, but it would not be the same. From time to time, I have taken a position to make changes and on several occasions I was all alone. My advice is to be bold, stand firm, and believe in yourself. I have believed that everything in practice and life can be improved with maximum effort and, therefore, I have come up with a line: Everything in life can be improved (CSR).

Albert Einstein claimed that the only rational way to educate is by example. Teaching, education, and research have always been important to me. I am going to present a practical example of what I have done. As you know, I came from India. I have given my time and financial resources, since the late 1980 s, to teach Indian orthopedic surgeons through a Fellowship Program and Continuing Education courses. My team and I are proud to say that we have trained 45 orthopedic surgeons through the Ranawat Orthopaedic Research Foundation Fellowship Program (RORF); $90 \%$ of them have returned to India to practice orthopedic surgery. I have carried out nine (9) Continuing Education courses to date. The next one is in Chennai, India, during the month of June with around 400 orthopedic surgeons attending.

My family and I are committed to philanthropy. The Ranawat Family Trust has decided to support various educational missions. Our family trust continues to donate to the Orthopaedic Research and Education Foundation, The Hospital For Special Surgery, and the Ranawat Orthopaedic Research Foundation. A substantial amount is being donated to Duke University and the Eastern Orthopaedic Educational Foundation and a few loyal employees.
So what I want from you all is to think to give back to the country and profession. I hope that many of you will become important and successful physicians and surgeons, and when that happens you will want to give back your personal time, money, intellect to your country, profession, the special people in your life and your family.

I have analyzed how success comes in life. A successful life embodies many qualities, but the important ones are self-discipline, self-reliance, and self-motivation. Back in 1958, after my graduation, I made the commitment to rise at 5:30 AM, go to work, and work for at least 10 to 12 hours, a schedule I follow to this day. To succeed in life you must establish your goals, develop a passion and plan of action for achieving them. Allocate the necessary resources and always periodically reassess your goals and your progress towards achieving them.

And so, graduates of 2009, I leave with you three important thoughts for success and being a good person:

1. To succeed in life one needs good health, peace within yourself, wisdom to make the right decisions, sense of fairness and honesty, and above all, the desire to do better every day.

2. It takes days, months and even years to build a relationship; however, it takes only 30 seconds to destroy it by uttering insulting or inappropriate remarks.

3. Professional success is important; however, in real life one's family is what really matters. Do not ignore this aspect of your life.

Finally, some of you will become leaders in the near future. Let me give you my thoughts on the qualities of a leader: A leader has the ability to identify, differentiate, and define a complex problem in a manner that everyone can understand; he surrounds himself with loyal, smart and knowledgeable people.

I conclude by wishing all of you the best our profession has to offer, happiness in your personal life, become a leader, succeed, and make the difference. God bless you all and God Bless America.

Please rise and give a big round of applause to the graduating Class of 2009.

Chitranjan Ranawat, M.D.

American Academy of Orthopedic Surgeons

Annual Meeting 2009 